\title{
Investigation of the Attitudes of Physical Education Teacher Candidates toward Teaching Profession and Sense of Competence in Terms of Some Variables
}

\author{
Talha Murathan ${ }^{1} \&$ Kübra Özdemir ${ }^{1}$ \\ ${ }^{1}$ School of Physical Education and Sports, Department of Sport Management, Ardahan University, Ardahan, \\ Turkey \\ Correspondence: Talha Murathan, School of Physical Education and Sports, Department of Sport Management, \\ Ardahan University, Ardahan, 75000, Turkey. E-mail: talhamurathan@ardahan.edu.tr
}

Received: June 20, 2017

Accepted: June 30, 2017

Online Published: July 25, 2017

doi:10.5539/jel.v6n4p229

URL: http://doi.org/10.5539/jel.v6n4p229

\begin{abstract}
The purpose of this study was to examine the attitudes of physical education teacher candidates toward the teaching profession and the perceptions of professional competence according to some variables. A total of 351 teacher candidates, studying in the last class of Physical Education and Sport Teaching Department in the Faculty of Sports Sciences and Physical Education and Sports Schools were enrolled as the research group. "Attitude Scale Related to Teacher Education", "The Candidate Teacher's Proficiency Perception Scale" and "Personal Information Form" developed by the researchers were applied on the study subjects to collect the data. It was found that according to the universities, there are differences in the perception of professional competence but there is no difference in attitude. It was also found that there is no meaningful difference between professional perceptions and teaching attitudes in terms of sport branches, the situation in which the education section is selected voluntarily or not.
\end{abstract}

Keywords: teacher candidate, physical education, professional attitude, sense of competence, teacher

\section{Introduction}

Education is the development of an individual's mental, physical, emotional and social skills and behaviors in a most appropriate or desired direction, and incorporates a set of instructions to teach new skills and behaviors and information to meet some purposes (Akyüz, 2009). In this perspective, learning and teaching activities have a long history and probably have begun with the existence of human beings and will end with the end of life on the earth.

In the earlier times, the main means of education were through a simple one-to-one tutorial, but with the proliferation of human generation and the diversification of the requirements, the need for learning and teaching has also increased (Hoşgörür, K1lıç, \& Dündar, 2002). As a result, educational institutions emerged and teachers possessing the higher education and professional qualifications were bestowed with the charge. Teaching is accepted as a profession of professional status and has individual, social, cultural, scientific and technological dimensions (Kara, 2004; Uygun, 2008). Teaching profession requires adequate equipment depending on individual social, cultural, economic, and scientific environments. According to Kavcar (1987), the success of the education system depends mainly on the characteristics of the teachers and other education workers who operate and implement the system. No education model can provide services above the qualifications of the employees who operate the model. Therefore, a school can only be said to be as good as its faculty members.

The preference of individuals for the right profession affects largely their positive behaviors toward their profession (Bozdoğan, Aydın, \& Yıldırım, 2007; Kara, 2008). The ability of teachers to fulfill their responsibilities and improve the quality of the education system requires developing positive attitudes toward the pre-service phase of their profession and sensory domain competencies. The performance of the teachers, who are fond of their profession and having a positive attitude toward the profession, will be better (Hussain, Ali, Khan, Ramzan, \& Qadeer, 2011; İzci \& Kara, 2010). In this regard, having positive attitudes and values regarding the profession is seen as a determinant of the teachers' achievements in professional life (Kara, 2004; Karadağ, 2012; Özden \& Kara, 2006). Attitudes toward the profession, individual feelings and behaviors 
represent the commitment to the profession (Hussain et al., 2011; Kara et al., 2013; Kara, Demirbağ, \& Işık, 2013). In addition to occupational attitudes, professional competence is also very important for an individual's professional success. Competence perception is defined as an ability of individuals to meet certain expected performance and to organize the actions necessary to do so and their judgments or beliefs about the capacity to carry out these expected actions (Bandura, 1986). Vocational competence, along with the necessary knowledge while carrying out a profession, implies using it effectively to fulfill the duties and responsibilities. In this sense, the individual's attitude will not be enough alone, and his perception of proficiency would also be very important. When self-competence and positive attitudes are combined, success and happiness become inevitable.

In our country, it has been observed that one of the most important problems related to the education system in recent years is teacher training and the quality of the teachers. The competence of teacher candidates related to the teaching profession and their attitudes toward the teaching profession are important in determining the nature of the teachers being educated. The facilities that the faculties of education possess (economic situation, the number of teaching staff, building, facility status, etc.) play a great role in perceiving themselves as professionally competent and gaining positive attitudes toward teaching profession (Çapri \& Çelikkaleli, 2008). The efficiency and effectiveness of teacher training programs can be evaluated by the positive attitudes and high self-competence perceptions of the candidate teachers who graduated from the program (Çakır, Kan, \& Sümbül, 2006).

Considering the importance of teacher candidates' attitudes toward the teaching profession as well as their self-competence, it is necessary for the candidates to be examined for their professional attitudes and self-competence while performing the teaching profession. For this purpose, in this descriptive study, it was tried to determine the attitudes of the teacher candidates in the last class of Physical Education and Sport Teacher Education of ten different universities toward the teaching profession and perceptions of competence.

\section{Material and Method}

\subsection{Participants}

A research group was formed by randomly recruiting 351 prospective teachers, who were attending to the Sports Science Faculties and the Physical Education and Sports Schools in the Physical Education and Sports Teaching Department of ten universities in different region of Turkey.

\subsection{Method}

In the study, Physical Education Teacher Candidates' attitudes toward the teaching profession and their perceptions of competence were aimed to evaluate following the variables such as gender, university, sports branches, monthly income situation, age and whether or not the department is selected voluntarily. The data were collected on a Likert-type "Teacher Profession Attitude Scale" and the Attitudes for Teaching Profession were analyzed quantitatively by using descriptive scanning model (Karasar, 2006).

\subsubsection{Data Collection Tools}

In the study, as the data collection tool, the "Teacher Attitude Scale", developed by Erkuş et al. (2000), was used in order to determine the attitudes of candidate teachers to the teaching profession and "Candidate Teacher Self-Perception Questionnaire for Self-Esteem" was used to measure their perception of competence (Çakır, Erkuş, \& Kılıç, 2004). The attitude scale for teacher education was of the Likert-type 5 and consisted of 22 items. Cronbach's alpha coefficient of internal consistency of the scale is .99 and the same calculated for the data obtained in this study was found to be .86. The Candidate Teacher's Perception of Self-Competence Scale was also of Likert-type 5 and consisted of 30 items. For this scale, Cronbach's alpha internal consistency coefficient is .80 , while the same for the data obtained in this study was calculated to be .88 . The items were scored from 1 to 5 and the scale was rated from the option "not at all suitable to me" (1) to the option "appropriate to me" (5). The lowest score that can be taken from the scale was " 30 " and the highest score was " 150 ".

Both scales were applied toward the end of the second semester of the 2015-2016 academic year after obtaining the necessary permissions for the students attending 10 different physical education and sport teaching programs.

\subsection{Data Analysis}

The relevant scales were applied to the teacher candidates in the study group and the obtained data were evaluated in SPSS package program. The evaluations were performed according to t-test and one-way analysis of variance (one-way ANOVA) for the obtained independent groups. In addition, Kruskal-Wallis and Mann-Whitney tests were also used to determine which group differs significantly from the others. 


\section{Results}

The statistical data are shown in Table 1 according to students' gender, age, the situations of whether or not the department is selected voluntarily, sports branches, monthly income levels, the place where the candidates lived for the longest time, and the points scored on "Attitude Scale for Teacher Education" and "Candidate Teacher's Perception of Self-Sufficiency Scale".

Table 1. Demographic information

\begin{tabular}{|c|c|c|c|}
\hline & & $\mathrm{n}$ & $\%$ \\
\hline \multirow{10}{*}{ University } & Ardahan University & 35 & 10.0 \\
\hline & Frrat University & 38 & 10.8 \\
\hline & Gazi University & 37 & 10.5 \\
\hline & Ağrı İbrahim Çeçen University & 36 & 10.3 \\
\hline & Karadeniz Technical University & 35 & 10.0 \\
\hline & Sakarya University & 35 & 10.0 \\
\hline & Erzurum Atatürk University & 32 & 9.1 \\
\hline & Dicle University & 34 & 9.7 \\
\hline & Mersin University & 35 & 10.0 \\
\hline & Kayseri Erciyes University & 34 & 9.7 \\
\hline \multirow{2}{*}{ Gender } & Male & 245 & 69.8 \\
\hline & Female & 106 & 30.2 \\
\hline \multirow{14}{*}{ Sports Branch } & Athleticism & 29 & 8.3 \\
\hline & Badminton & 9 & 2.6 \\
\hline & Basketball & 22 & 6.3 \\
\hline & Boxing & 16 & 4.6 \\
\hline & Football & 77 & 21.9 \\
\hline & Wrestling & 25 & 7.1 \\
\hline & Handball & 13 & 3.7 \\
\hline & Karate & 7 & 2.0 \\
\hline & Ski & 8 & 2.3 \\
\hline & Tennis & 16 & 4.6 \\
\hline & Volleyball & 38 & 10.8 \\
\hline & Swimming & 7 & 2.0 \\
\hline & Other & 48 & 13.7 \\
\hline & No & 36 & 10.3 \\
\hline \multirow{3}{*}{ Monthly Income Level } & $0-1000 \mathrm{TL}$ & 221 & 63.0 \\
\hline & $1001-2000 \mathrm{TL}$ & 91 & 25.9 \\
\hline & $2001 \mathrm{TL}$ and over & 39 & 11.1 \\
\hline \multirow{2}{*}{$\begin{array}{l}\text { Have you chosen voluntarily the Department of } \\
\text { Education? }\end{array}$} & Yes & 342 & 97.4 \\
\hline & No & 9 & 2.6 \\
\hline \multirow{3}{*}{ The place you live the longest } & Provincial Center & 244 & 69.5 \\
\hline & County/Town & 66 & 18.8 \\
\hline & Village/hamlet & 41 & 11.7 \\
\hline
\end{tabular}




\begin{tabular}{llrr}
\hline & 21 and under & 101 & 28.8 \\
Age & 22 years & 108 & 30.8 \\
& 23 years & 60 & 17.1 \\
& 24 years & 37 & 10.5 \\
& 25 years & 21 & 6.0 \\
& 26 years and over & 24 & 6.8 \\
\hline
\end{tabular}

Table 1 shows the demographic information of the participants. Among the participants, $69.8 \%$ were male and $30.2 \%$ were female. Regarding the sports, $21.9 \%$ were from football, $10.8 \%$ from volleyball, $8.3 \%$ from athletics, and $7.1 \%$ from wrestling. The majority of the teacher candidates $(63.0 \%)$ had a monthly income between $0-1000$ TL. Most of them (97.4\%) voluntarily selected the department where they were studying. The place where $69.5 \%$ of people lived the longest was the city center. The age group of the participants varied between 20-35 years.

Table 2. Descriptive statistics of participants' scale scores

\begin{tabular}{lccccc}
\hline & N & Minimum & Maximum & Mean & Standard deviation \\
\hline Attitude & 351 & 22 & 110 & 73.9 & 11.3 \\
Sense of Competence & 351 & 30 & 150 & 119.9 & 22.55 \\
\hline
\end{tabular}

Table 2 shows descriptive statistics for the participants' scale scores. The average attitude score was 73.94 and the average score of the Sense of Competence was 119.9.

Table 3. Normality tests of scale scores

\begin{tabular}{lcc}
\hline & Shapiro-Wilk & $\mathrm{P}$ \\
\hline Attitude & .864 & .000 \\
Sense of Competence & .878 & .000 \\
\hline
\end{tabular}

As shown in Table 3, according to the Shapiro-Wilk test for normality of the scale scores, Attitude and Proficiency Perception scores did not show a normal distribution $(p<0.05)$, therefore nonparametric methods were used in the comparison analysis.

Table 4. Kruskal Wallis test results in terms of universities

\begin{tabular}{|c|c|c|c|c|c|}
\hline Universities & & $\mathrm{N}$ & Sira Ortalama & $\mathrm{X}^{2}$ & $\mathrm{P}$ \\
\hline \multirow{10}{*}{ Attitudes } & Ardahan University & 35 & 181.66 & \multirow{10}{*}{7.273} & \multirow{10}{*}{.609} \\
\hline & Furat University & 38 & 164.39 & & \\
\hline & Gazi University & 37 & 180.47 & & \\
\hline & Ağr1 İbrahim Çeçen University & 36 & 163.15 & & \\
\hline & Karadeniz Technical University & 35 & 177.97 & & \\
\hline & Sakarya University & 35 & 169.06 & & \\
\hline & Erzurum Atatürk University & 32 & 202.52 & & \\
\hline & Dicle University & 34 & 175.26 & & \\
\hline & Mersin University & 35 & 197.30 & & \\
\hline & Erciyes University & 34 & 150.85 & & \\
\hline Sense of Competence & Ardahan University & 35 & 162.64 & 31.868 & $.000 *$ \\
\hline
\end{tabular}




\begin{tabular}{lll}
\hline Frrat University & 38 & 195.38 \\
Gazi University & 37 & 173.09 \\
Ağrı İbrahim Çeçen University & 36 & 167.72 \\
Karadeniz Technical University & 35 & 129.44 \\
Sakarya University & 35 & 140.13 \\
Erzurum Atatürk University & 32 & 231.41 \\
Dicle University & 34 & 151.16 \\
Mersin University & 35 & 210.16 \\
Erciyes University & 34 & 202.40 \\
\hline
\end{tabular}

There was no statistically significant difference between attitudes toward teaching profession in terms of universities $(p>0.05)$ (Table 4). On the other hand, according to Kruskal-Wallis test, there was a statistically significant difference in the terms of teachers' sense of competence in the terms of the university in which the education was taken $(p<0.05)$. According to this, it was determined that the perception of the teachers who were studying at Erzurum Atatürk University was higher than those who were studying at other universities. The lowest point average was seen in the participants at the Karadeniz Technical University.

Table 5. Mann-Whitney U test results by gender

\begin{tabular}{llcccc}
\hline Gender & & $\mathrm{N}$ & Rank Average & $\mathrm{U}$ & $\mathrm{p}$ \\
\hline \multirow{2}{*}{ Attitude } & Male & 245 & 178.36 & 12407.500 & .508 \\
& Female & 106 & 170.55 & & \\
\hline \multirow{2}{*}{ Sense of Competence } & Male & 245 & 172.77 & 12193.000 & .364 \\
& Female & 106 & 183.47 & & \\
\hline
\end{tabular}

In the comparison of scale scores in the terms of gender according to the Mann-Whitney test, there was no statistically significant difference in the attitude and competence perception scores $(p>0.05)$ (Table 5). According to this, there is no significant difference between the attitudes of female and male students toward the teaching profession and their sense of competence.

Table 6. Kruskal Wallis test results in terms of sports branches

\begin{tabular}{llcccc}
\hline Scale & Branch & N & Rank Average & $X^{2}$ & $p$ \\
\hline Athleticism & 29 & 132.41 & \\
Badminton & 9 & 106.44 & & \\
Basketball & 22 & 190.57 & 156.63 & \\
Boxing & 16 & 186.57 & .065 \\
Football & 77 & 193.56 & \\
Attitude & Wrestling & 25 & 228.38 & \\
Handball & 13 & 197.14 & \\
Karate & 7 & 174.06 & \\
Ski & 8 & 211.78 & \\
Tennis & 16 & 172.53 & \\
Volleyball & 38 & 108.07 & \\
Swimming & 7 & 169.88 & \\
\hline
\end{tabular}




\begin{tabular}{llcl}
\hline None & 36 & 179.94 \\
\hline Athleticism & 29 & 165.45 \\
Badminton & 9 & 218.56 \\
Basketball & 22 & 158.20 \\
Boxing & 16 & 202.91 \\
& Football & 77 & 177.42 \\
Wrestling & 25 & 175.94 \\
& Handball & 13 & 161.08 \\
& Karate & 7 & 172.71 \\
& Ski & 8 & 178.25 \\
& Tennis & 16 & 220.94 \\
& Volleyball & 38 & 183.34 \\
Swimming & 7 & 151.36 \\
Other & 48 & 177.77 \\
None & 36 & 150.01 \\
\hline
\end{tabular}

According to Kruskal-Wallis test, there is no statistically significant difference between the attitudes toward the teaching profession and the self-competence in the terms of branches of teacher candidates participating in the survey (Table 6).

Table 7. Kruskall Wallis test results in terms of monthly income

\begin{tabular}{llcccc}
\hline & Monthly Income & $\mathrm{N}$ & Rank Average & $\mathrm{X}^{2}$ & $\mathrm{P}$ \\
\hline \multirow{3}{*}{ Attitudes } & $0-1000 \mathrm{TL}$ & 221 & 175.11 & & .191 \\
& $1001-2000 \mathrm{TL}$ & 91 & 167.02 & 3.307 & \\
& $2001 \mathrm{TL}$ and over & 39 & 202.03 & & .817 \\
\multirow{3}{*}{ Sense of Competence } & $0-1000 \mathrm{TL}$ & 221 & 176.62 & 171.34 & \\
& $1001-2000 \mathrm{TL}$ & 91 & 183.35 & & \\
& $2001 \mathrm{TL}$ and over & 39 & & \\
\hline
\end{tabular}

As seen in Table 7, according to Kruskal-Wallis test results, there were no significant differences in the teacher attitudes toward their professions and self-competence in terms of monthly incomes $(p>0.05)$.

Table 8. Mann-Whitney test results according to whether or not the department is delected voluntarily

\begin{tabular}{llllll}
\hline & Have you choosen the & $\mathrm{N}$ & Rank Average & $\mathrm{U}$ & $\mathrm{p}$ \\
& department voluntarily? & & & 1495.000 & .883 \\
Attitude & Yes & 342 & 175.87 \\
& No & 9 & 180.89 & 1365.000 & .562 \\
\hline \multirow{2}{*}{ Sense of Competence } & Yes & No & 9 & 156.67 & 176.51 \\
\end{tabular}

As seen in Table 8, from the point of view of whether or not the part of education is selected voluntarily, there was no statistically significant difference between the scores of the teacher candidates' attitudes toward teaching profession and self-competence $(p>0.05)$. 
Table 9. Kruskal Wallis test results in terms of the longest lived place

\begin{tabular}{llcccc}
\hline & The Longest Lived Place & $\mathrm{N}$ & Rank Average & $\mathrm{X}^{2}$ & $\mathrm{p}$ \\
\hline \multirow{3}{*}{ Attitude } & City Center & 244 & 173.19 & & .809 \\
& County/Town & 66 & 179.04 & .667 \\
& Village/Hamlet & 41 & 187.85 & \\
\hline \multirow{3}{*}{ Sense of Competence } & City Center & 244 & 172.29 & 3.424 & .180 \\
& County/Town & 66 & 172.59 & 203.55 & \\
\hline
\end{tabular}

According to the results of Kruskal-Wallis test, the differences observed in the mean scores of the longest-lived places were not statistically significant $(p>0.05)$.

Table 10. Kruskal Wallis test results in terms of ages of teacher candidates

\begin{tabular}{|c|c|c|c|c|c|}
\hline & Age & $\mathrm{N}$ & Rank Average & $\mathrm{X}^{2}$ & $\mathrm{p}$ \\
\hline \multirow{6}{*}{ Attitude } & 21 and under & 101 & 181.93 & \multirow{6}{*}{1.539} & \multirow{6}{*}{.908} \\
\hline & 22 years & 108 & 174.15 & & \\
\hline & 23 years & 60 & 175.32 & & \\
\hline & 24 years & 37 & 182.51 & & \\
\hline & 25 years & 21 & 170.31 & & \\
\hline & 26 years and over & 24 & 156.00 & & \\
\hline \multirow{6}{*}{$\begin{array}{l}\text { Sense of } \\
\text { Competence }\end{array}$} & 21 and under & 101 & 160.27 & \multirow{6}{*}{7.814} & \multirow{6}{*}{.167} \\
\hline & 22 years & 108 & 170.06 & & \\
\hline & 23 years & 60 & 182.51 & & \\
\hline & 24 years & 37 & 209.16 & & \\
\hline & 25 years & 21 & 189.60 & & \\
\hline & 26 years and over & 24 & 189.67 & & \\
\hline
\end{tabular}

As can be seen in Table 10, there was no significant difference in terms of the sense of competence and attitudes toward the teaching profession in terms of the age of teacher candidates.

\section{Discussion}

The most important element in determining the quality of education is undoubtedly the teachers, who have the greatest influence and power in the teaching process. Teacher candidates' positive perceptions and attitudes toward the teaching profession will make them active and effective at the onset of their career. Positive perceptions and attitudes are effective in the development of personality, thus a positive relationship between a teacher and student can make learning more active (Kara, İzci, \& Murathan, 2011; Semerci N. \& Semerci C., 2004; Semerci \& Kara, 2004).

In this study, the attitudes and profession perceptions about the teaching profession of 351 teacher candidates trained at 10 universities in the last year of Physical Education and Sports Teaching Department were investigated. In general, it has been observed that the attitudes and competence perceptions of the teacher candidates about the teaching profession are very positive. Ayık and Ataş (2014), Gülşen and Seyratlı (2014), Kara et al. (2011) obtained similar results.

Although there was no difference in the attitude perceptions according to the university where the teacher candidates were being trained, significant differences were found in the sense of competence. The students of Karadeniz Technical University had the lowest score in terms of sense of competence and the students of Atatürk University had the highest average score. Bulut (2010) worked with 411 teacher candidates who were studying in Primary School Teaching, Science Teaching and Social Sciences Teaching Department in the Faculty of 
Education of Dicle and Firat Universities and observed that there was no difference in the attitude scale according to the university variable. In the same work, a significant difference was noted according to the variable of the department.

The attitude and sense of competence scores did not show statistically significant differences according to gender. This observation concords very well with the literature (Açışlı \& Kolomuç, 2012; Bulut, 2010; Gülşen \& Seyratlı, 2014; Öksüzoğlu, 2009). Unlike our findings, Çapri and Çelikkaleli (2008) reported that gender has a significant effect on attitude and the sense of competence scales. Üstüner et al. (2009) found that women had a significantly higher score than men in their attitudes toward the teaching profession. Similar results were obtained by Aydın and Sağlam (2012), Durmuşoğlu, Yanık, and Akkoyunlu (2009), Oral (2004), Terzi and Tezci (2007). According to Bandura's (1977) self-efficacy theory, there should be no difference between men and women about how much they feel enough. In this study, it can be said, in general, that female and male candidate teachers have similar attitudes and the gender variable is not effective on the attitude and competence perception.

The age range of the teacher candidates participating in the study was 20-35 years. According to the age variable, no significant differences were found in terms of the attitude and sense of competence scores. Similarly, there were no differences in the attitude and sense of competence according to the variables of longest living place, the amount of monthly income, the sports branches and, the department where the education was taken. Unlike our findings, in his study, Öksüzoğlu (2009) concluded that the sense of competence score average of teacher candidates coming voluntarily was higher than those coming unwillingly and the difference between the groups was also significant.

As a result, it was determined that the sense of competence increases when candidate teachers' attitudes toward the profession are positive. In order to gain a positive attitude and behavior toward the teaching profession in the teacher candidates, who are studying in the department of physical education and sports teaching, the techniques like enhancement of the practical course hour, symposiums, encouraging students to attend to panels and conferences as listeners and teaching practices can be developed.

\section{References}

Açışl1, S., \& Kolomuç, A. (2012). Study of The Would-be Class Teachers' Attitude Towards The Profession. Journal of Research in Education and Teaching, 1(2), 2146-9199.

Akyüz, Y. (2009). Turkish Education History (B.C. 1000-A.D. 2009). Ankara, Pegem Academi Publications.

Aydın, R., \& Sağlam, G. (2012). Teacher Applicant's View Directed Towards to Profession of Teacher (Example of Mehmet Akif Ersoy University). The Journal of Turkish Educational Sciences, 10(2), 257-294.

Ayık, A., \& Ataş, Ö. (2014). The Relationship Between Pre-service Teachers' Attitudes Towards the Teaching Profession and Their Motivation to Teach. Journal of Educational Sciences Research. E-Journal, 4(1), 25-43. https://doi.org/10.12973/jesr.2014.41.2

Bandura, A. (1977). Social Learning Theory. New Jersey: Prentice-Hall, Inc, Engkewood.

Bandura, A. (1986). Social Foundation of Thought and Action: A Social Cocnitive Theory. Englewood Cliffs, NJ: PrenticeHall.

Bozdoğan, A. E., Aydın, D., \& Yıldırım, K. (2007). Attitudes of Teacher Candidates Towards Teaching Profession. Journal of Kirşehir Education Faculty, 8(2), 83-97.

Bulut, İ. (2010). Evaluation of Teacher Candidates' Attitudes Concerning Teaching Profession (Dicle and Firat University Sample). Journal of Ziya Gökalp Faculty of Education, 14, 13-24.

Çakır, Ö., Erkuş, A., \& Kılıç, F. (2004). Evaluation of Several Variables of Mersin University Faculty of Education teaching profession 1999-2000 year program (ÖMBP). Mersin University Publications.

Çakır, Ö., Kan, A., \& Sünbül, Ö. (2006). The Evaluation of the Teaching Certificate Program and the Masters Program without Thesis with respect to Students' Attitudes and Self-efficacy. Mersin University Journal of the Faculty of Education, 2(1), 36-47.

Çapri, B., \& Çelikkaleli, Ö. (2008). Investigation of Preservice Teachers' Attitudes Towards Teaching and Professional Self-Efficacy Beliefs According to Their Gender, Programs and Faculties. Inonu University Journal of the Faculty of Education, 9(15), 33-53.

Durmuşoğlu, M. C., Yanık, C., \& Akkoyunlu, B. (2009). Turkish and Azerbaijani Prospective Teachers' Attitudes to Their Profession. Hacettepe University Journal of Education, 36, 76-86. 
Erkuş, A., Sanlı, N., Bağl1, M. T., \& Güven, K. (2000). Developing an Attitude Scale Toward Teaching as a Profession. Education and Science, 25(116), 27-34.

Gülşen, C., \& Seyratlı, E. (2014). The Attitudes of Teacher Candidates Towards Their Profession who Take Teacher Certificate Program. Journal of Research in Education and Teaching, 3(3), 2146-9199.

Hoşgörür, V., Kılıç, Ç., \& Dündar, H. (2002). Attitudes of Kırıkkale University Elementary Education Students to Profession of Teaching. Journal of Educational Sciences, 16, 91-100.

Hussain, S., Ali, R., Khan, M. S., Ramzan, M., \& Qadeer, M. Z. (2011). Attitude of Secondary School Teachers Towards Teaching Profession. International Journal of Academic Research, 3(1), 985-990.

İzci, E., \& Kara, A. (2010). The Inservice Training of The Teaching Staff in France. Adlyaman Üniversity Journal of Social Sciences Institute, 3(5), 161-168.

Kara, A. (2004). The Affect of a Curriculum Based on Affective Dimension to the Affective Development and Academic Achievement of Students (a sample of Adlyaman province) (PhD Thesis). Firat University Social Sciences Institute, Elazığ, Turkey.

Kara, A. (2008). Adaptation of the "Echelle de Motivation en Education" Scale to Turkish. Ege Journal of Education, 9(2), 59-78.

Kara, A., Demirbağ, B., \& Işık, A. (2013). Farklı Liselerde Görev Yapan Öğretmenlerin Öğrenmeye İlişsin Tutumlarinin İncelenmesi. International Perspectives on New Aspects of Learning in Teacher Education IPALTE, Dicle University, Ziya Gökalp Faculty of Education Diyarbakir/Turkey.

Kara, A., Demirbağ, B., Ünişen, A., \& Arıbaş, S. (2013). Investigation of Attitudes towards Learning and Teaching Profession of the Four-Year Undergraduate Degree and Graduate Pedagogical Formation Teachers' Candidates. International Perspectives on New Aspects of Learning in Teacher Education IPALTE, Dicle University, Ziya Gökalp Faculty of Education Diyarbakir/Turkey.

Kara, A., İzci, E., \& Murathan, F. (2011). The Habit of The Evaluation of The Free Time and The Attitudes Toward Learning of The Physical Education Teachers. e- Journal of New World Sciences Academy, 6(1), 958-987.

Karadağ, R. (2012). The Attitudes of Turkish Teacher Candidates Towards Teaching Profession and Their Reasons for Selecting the Teaching Profession. Humanities Sciences, 7(2), 44-66.

Karasar, N. (2006). Scientific Method of Research (16.Press). Nobel Ankara.

Kavcar, C. (1987). Yüksek Öğretmen Okulunun Öğretmen Yetiştirmedeki Yeri. Ankara.

Oral, B. (2004). The Attitudes of Students of Education Faculty Towards Teachıng Proffessions. Eurasian Journal of Educational Research, 15, 88-98.

Öksüzoğlu, P. (2009). Self Perceptions of on Proficiency in Teaching Profession Physcical Education Teacher Candidates (MsC Thesis). Mersin University, Graduate of School of Medical Sciences, Mersin/Turkey.

Özden, M., \& Kara, A. (2006). Attitudes of 8th and 10th Grade Students' Toward Chemistry Lessons. Sakarya University Journal of Education Faculty, 11, 1-14.

Semerci, Ç., \& Kara, A. (2004). The Effects of Teaching Profession Courses on Doctoral Students' Attitudes Towards The Teaching Profession. Education and Science, 29(131), 70-77.

Semerci, N., \& Semerci, Ç. (2004). Teacher Attitudes in Turkey. Firat University Journal of Social Science, 14(1), 137-146.

Terzi, A. R., \& Tezci, E. (2007). The Attitudes of the Students Towards Teaching Profession at Necatibey Education Faculty. Educational Administration: Theory and Practice, 52, 593-614.

Uygun, S. (2008). Ortaöğretim Sosyal Alanlar Bölümünde Okuyan Öğretmen Adaylarının Mesleğe Yönelik Duyarlılıkları. I. Uluslar arası Sosyal Bilimler Eğitimi Sempozyumu, Çanakkale/Türkiye.

Üstüner, M., Demirtaş, H., \& Cömert, M. (2009). The Attitudes of Prospective Teacher Towards the Profession of Teaching (The Case of Inonu Univercity, Faculty of Education). Education and Science, 34(151), 140-155. 


\section{Copyrights}

Copyright for this article is retained by the author(s), with first publication rights granted to the journal.

This is an open-access article distributed under the terms and conditions of the Creative Commons Attribution license (http://creativecommons.org/licenses/by/4.0/). 